Dr. Hanan Gamal Mohamed Ebedy

\title{
Using Explicit Instruction versus Incidental Learning in Enhancing Lexical Collocational Knowledge and Quality of Writing
}

\author{
By \\ Dr. Hanan Gamal Mohamed Ebedy \\ Lecturer of Curriculum and Instruction (TEFL) \\ Misr University for Science and Technology
}

\begin{abstract}
This study was conducted to investigate the effectiveness of using explicit instruction versus incidental learning in enhancing lexical collocational knowledge among third-year English majors at the Faculty of Foreign Languages and Translation, Misr University for Science and Technology. For the purposes of this study, 60 students were divided into two experimental (i.e. explicit instruction and incidental learning) and one control group. A lexical collocation test which consists of two parts, namely, receptive and productive, and a writing quality test were administered for three groups after the treatment. A 10-session treatment was administered for the experimental groups' students, while the control group students followed their regular method. Results revealed a clear advantage for explicit instruction as the explicit instruction group significantly outperformed the incidental learning group and the control group both in receptive and productive lexical knowledge. Results also indicated that the explicit instruction group students outperformed both the incidental and the control groups in the quality of writing. The incidental learning group also reflected some collocation gains with better performance than the control group.
\end{abstract}

Keywords: Explicit Instruction, Incidental Learning, Lexical Collocation 
Using Explicit Instruction versus Incidental Learning in Enhancing

Lexical Collocational Knowledge and Quality of Writing

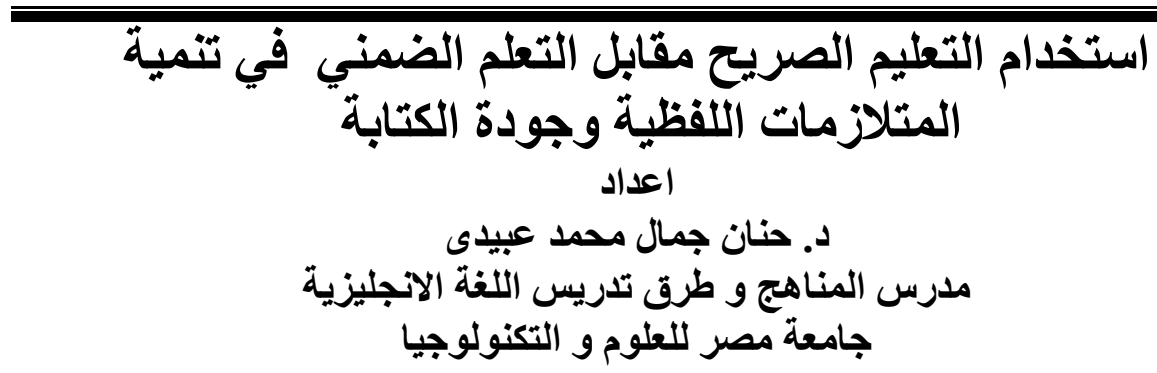

المستخلص أجريت هذه الاراسة لبحث فاعلية استخدام التعليم الصريح مقابل التعلم الضمني

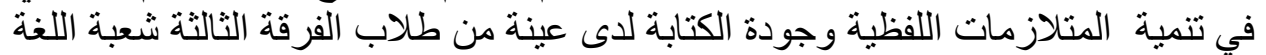
الإنجليزية بكلية اللغات والترجمة، جامعة مصر للعلوم والتكنولوجيا. و تكونت عينة

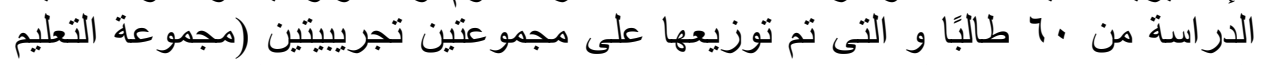

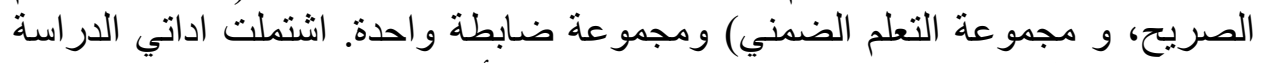

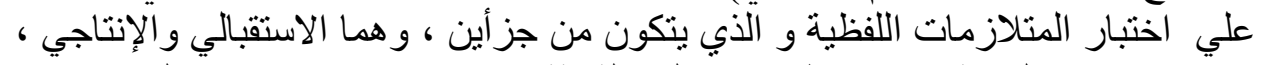

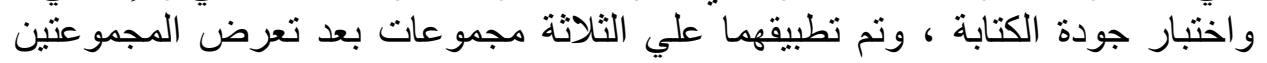

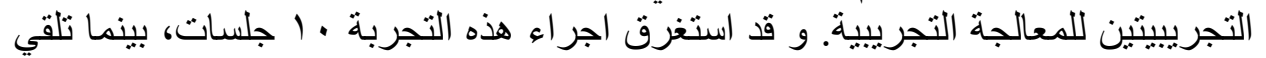

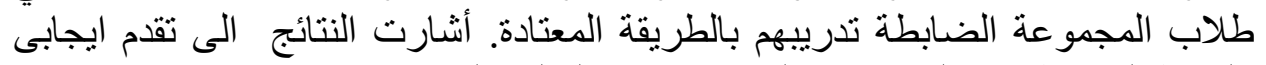

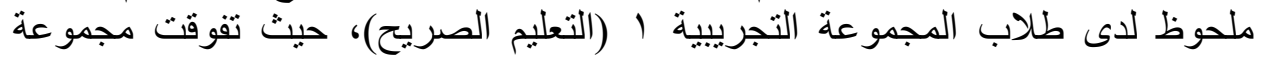

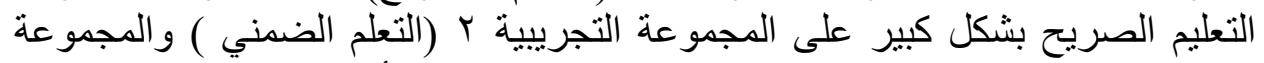

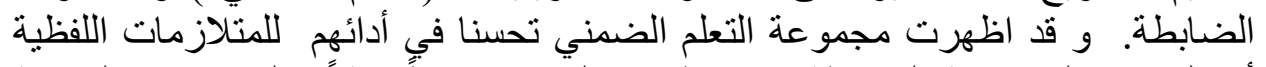

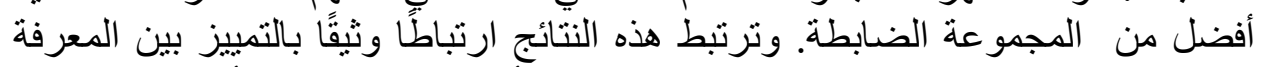

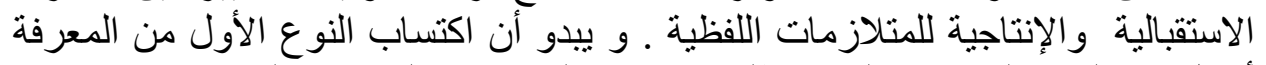

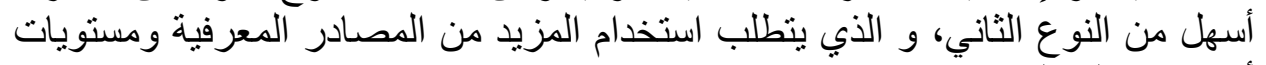
أعمق من المعالجة.

الكلمات المفتاحية: التعليم الصريح ـ التعلم الضمني ـ المتلازمات اللفظية

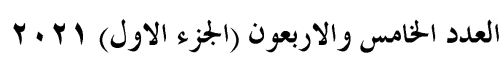

(14)

مجلة كلية التربية- جامعة عين شمس 
Dr. Hanan Gamal Mohamed Ebedy

\title{
Using Explicit Instruction versus Incidental Learning in Enhancing Lexical Collocational Knowledge and Quality of Writing
}

\author{
By \\ Dr. Hanan Gamal Mohamed Ebedy \\ Lecturer of Curriculum and Instruction (TEFL) \\ Misr University for Science and TechnologyIntroduction
}

Learners of a foreign language need a massive amount of vocabulary to achieve any kind of functional proficiency, which poses a seemingly insuperable challenge for successful communication. Our ability to perceive and produce language is directly or indirectly dependent upon our word store or more accurately lexical and collocational competence. The importance of lexical collocation knowledge has been widely recognized and strongly advocated by foreign language researchers as a tool to develop higher level of productive skills in advanced learners.

The benefits of learning collocations are currently viewed as extending beyond mere word selection to include fluency development as well as improvements in accuracy (Wray, 2000; ElDakhs, Amrounand Muhammad, 2018; Goulart, 2019; and Mahvelati, 2019). With numerous gains anticipated, a high concern is added to the contribution of collocations in the language classroom and the call for more explicit instruction to be accorded to their teaching in the curriculum (Lewis, 2000). In spite of the widely acknowledged difficulties learners have in producing collocations and their critical role in fluency development, very few empirical studies have addressed the issue of how collocations can be most effectively taught in the language classroom (GabrysBiskup, 1992; Bahns \& Eldaw, 1993; Nesselhauf, 2003; ElDakhs, 2015; and Goulart, 2019). 


\section{Using Explicit Instruction versus Incidental Learning in Enhancing}

Lexical Collocational Knowledge and Quality of Writing

The crucial role played by collocations both at the receptive and productive levels in language learning gives it an added attention and place among language components. Predicting the content in upcoming texts is the fruit of collocations attainment (Carter \& McCarthy, 1988, p. 75). Learners' appropriate use of collocations reinforces their fluency, intelligibility and nativelikeness, and conversely, lack of collocational knowledge reveals one's foreignness (James, 1998, p. 152; and Nation, 2001, p. 318). Adequate attention should be accorded to teachingq collocations in foreign language classroom due to the crucial role they play in natural language use, versatility, and arbitrariness. Furthermore, collocations massively contribute to inferring word meaning, minimizing processing time of using the language and enhancing effective recognition and production of text encountered.

A growing amount of research probing learners' collocational knowledge at both the recognition and production levels has recently increased in response to the challenges they pose for many learners particularly in writing: Spanish (Fernandez \& Schmitt, 2015), Chinese (Fan, 2009; and Li \& Schmitt, 2010), Japanese (Webb \& Kagimoto, 2009), French (Granger \& Bestgen, 2014), Hebrew (Laufer \& Waldman, 2011), and German (Nesselhauf, 2005).

\section{Review of Literature}

Three categories of research orientations seem to represent the literature around learning and teaching collocations: a) studies related to probing learners' miscollocations, b) studies related to recognition and use of collocations through examining corpora and comparing native and nonnative uses of collocations, and c) studies related to introducing treatment material for developing collocations or using training on collocations to develop other language components. 


\section{Dr. Hanan Gamal Mohamed Ebedy}

As for the first category of studies addressing learners' miscollocations, Farghal and Obiedat (1995) examined learners' and instructors' competence in using collocations. Both freshmen and senior prospective teachers of English at Yarmouk University and their educators were evaluated by supplying missing words in a text about general notions like food, weather and color. Results reached were quite surprising as both of them lacked the elementary level of word combinations. Such a result made authors call for the necessity of paying adequate attention to incorporate collocations component in the curriculum of English.

The attempt was made by Kuo (2009) to analyze errors in the use of collocations by intermediate EFL college students in Taiwan. The instruments employed in the study consisted of writing samples under two topics and a collocation checker consolidated by two native judges to rate students' writings. Findings indicated that learners' pitfalls are due to negative transfer, use of synonyms and approximation.

The types and sources of verb-noun collocational errors were investigated by Hong, Rahim, Hua \& Salehuddin (2012). The analysis, covering 130 writing samples by Malay students, revealed that the most repeated errors was the preposition-related collocations. The highest frequency of all errors was intralingual transfer followed by overgeneralization and synonymy.

In a study by Shokouhi \& Mirsalari (2010) the attempt was made to explore the extent of correlation between linguistic background and acquisition of collocations using a proficiency test. Findings indicated that linguistic knowledge and use of collocations are not correlated.

The second orientation of studies includes Siyanova and Schmitt's study (2008) where they addressed problems in collocation intuition between native and nonnative speakers. Writing samples produced by Russian participants were analyzed resulting in insignificant differences between native and nonnative 


\section{Using Explicit Instruction versus Incidental Learning in Enhancing}

Lexical Collocational Knowledge and Quality of Writing

speakers in using collocations. Nonetheless, native speakers outperformed nonnatives in intuition of collocation frequency and processing. In a study by Alsakran (2011), the use of collocations by Saudi EFL learners was compared to that of Arab ESL learners where the first letter of the collocant and the meaning of the phrasal verb was given .Results showed that EFL learners were poorer than ESL learners in their performance in the tests. Findings also revealed that students' learning environment had its deep impact on both receptive and productive knowledge of collocations.

The third orientation of studies can be divided into two major types; studies that aim to develop the use of collocations, and studies that use collocations to develop other areas of language. Of the first category, Fan's study (2005) endeavoured to examine the effect of different levels of attention on the acquisition of verb collocations. Focusing on four levels, semantic processing, memorization for recall, rule given, and rule given in addition to giving impossible collocates, participants, totaling 94, at Mandarin University, were divided into the four levels of attention. Findings revealed that the rule-governed groups performed best in producing new collocations, judging miscollocations and recall passage collocations, whereas the semantic processing group performance was the poorest of all.

In a similar vein, Fahim \& Vaezi (2011) probed the use of visual/verbal input on enhancing verb-noun collocations among Iranian EFL Students. Two experimental groups, one having collocations capitalized or bolded and the other having collocations within enhanced visuals in the reading text, and a control group who didn't receive any collocations instruction. Results maintained that the experimental group who had visually enhanced collocations outperformed all their colleagues in the other two groups.

Utilizing blended learning, Seeink (2007) attempted to examine the effect of explicit instruction on enhancing writing

$$
\begin{aligned}
& \text { العدد الخامس والاربعون (الجزء الاول) الY r. } \\
& \text { جملة كلية التربية- جامعة عين شنس }
\end{aligned}
$$




\section{Dr. Hanan Gamal Mohamed Ebedy}

performance of six participants. Data gathering instruments consisted of a questionnaire, observation and journal writing samples in addition to interviews and reflections. Results indicated that explicit instruction of collocations significantly helped the treatment group improve their writing quality manifested in their rich use of collocations. In a similar vein, Amer (2010) was concerned with developing a mobile learning application to enhance learners' use of idiomatic expressions and collocations. Participants, totaling 45 , didn't gain above $70 \%$ and their usage of the application correlated with their mean scores on the collocation test.

The purpose of Falahi \&Moinzadeh (2012) and Webb and Kagimoto (2009) was to enhance collocations among Iranian and Japanese learners using receptive and productive tasks. Participants consisted of three groups, two experimental and one control. The first experimental group was given receptive tasks in the form of reading texts containing collocations whereas the second experimental group dealt with productive tasks in the form of cloze tests. No training was given to the control group. Findings indicated that both the experimental groups significantly developed collocational knowledge. Results of the Japanese study revealed that higher level learners handled productive tasks more effectively while lower level learners dealt better with receptive tasks.

In their attempt to determine what works better for collocation learning-explicit instruction or incidental learning (ElDakhs, Amroun \& Muhammad, 2018) conducted a study on a total of 114 female undergraduate native speakers of Arabic ranging in age between 18 and 20. The participants were recruited from a private Saudi university in Riyadh and admitted to their majors (i.e. Engineering, Law, Humanities, Business Administration and Computer and Information Science).

A multiple-choice test was devised to assess the learners' receptive knowledge. The learners' productive knowledge was assessed through a gap-filling test in which the participants supplied 


\section{Using Explicit Instruction versus Incidental Learning in Enhancing}

Lexical Collocational Knowledge and Quality of Writing

missing words in isolated sentences. Results came clearly in favor of explicit instruction. Nonetheless, findings also showed that incidental lexical learning was significantly useful for immediate achievement and less beneficial for explicit instruction.

Barani (2020) examined the effect of story comprehension on lexical collocational knowledge. The study was also concerned to determine the difference, if any, between grammatical and lexical collocation incidentally learned. Participants, totaling 28 Iranian EFL learners, were selected on the basis of their scores in a placement test and were divided into one experimental and one control group. Results indicated that students' collocational knowledge significantly improved, and their performance was higher on grammatical than lexical collocation.

On a parallel track, the second category of studies reported focused on collocations for developing other areas of language. Hsu \& Chiu (2008) assessed the effectiveness of training on collocations on the speaking proficiency of Taiwanese EFL learners. Findings indicated that learners' speaking performance and lexical collocational knowledge were significantly correlated. Nonetheless, students' use of collocations and their speaking performance were not correlated. This result highlights using collocations while speaking rather than perceiving them.

Thus, the scant number of studies exploring the effectiveness of input enhancement techniques as implicit methods of collocation instruction and mixed results reported by these studies highlight the need for conducting more research in this area. Additionally, the contention of implicit collocation instruction advocates that consider this method the best way or as viable as the explicit pedagogical techniques for teaching collocations cannot be rejected or supported without drawing direct comparison between explicit and implicit collocation teaching methods and the reflection of that on writing quality.

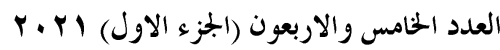

(20)
مجلة كلية التربية- جامعة عين شمس 


\section{Dr. Hanan Gamal Mohamed Ebedy}

\section{The Pilot Study}

The researcher conducted a pilot study on the third year English department at the Faculty of Languages and Translation, Misr University for Science and Technology in the $1^{\text {st }}$ semester of academic year 2020/2021. A test was administered to examine students' skill of recognizing and producing lexical collocations. Students were required to match words to create common English collocations, fill blank spaces with appropriate words, choose the right phrase from several collocations, use collocations to create sentences, and correct wrongly matched collocations.

After collecting students' answer sheets and checking their performance in writing, particularly using appropriate collocations, the researcher has found that:

- students mix between words that form collocations and other words of similar meaning; for example (say, tell); say the time, say jokes, tell thank you, tell something.

- they tend to use literal translation and refer to their L1; for example, to express that a person had an accident, they express it as make an accident, and to express that a person smokes a cigarette, many students wrote it as; drink $a$ cigarette.

- students mix between collocations and phrasal verbs, and idioms.

- students lack enough store of vocabulary to express, so collocations are a hard subject for students to study.

- it is hard for students to categorize types of word formation to differentiate collocations; verb-noun, noun-noun, adj-noun collocations.

- students lack practice of collocations at early age, and this negatively affects their collocational knowledge.

- students mix between Arabic and English collocations, so pupils form false lexical relationship between words to form collocations. 


\section{Using Explicit Instruction versus Incidental Learning in Enhancing}

Lexical Collocational Knowledge and Quality of Writing

\section{Statement of the problem}

English majors in the Faculty of Languages and Translation, Misr University for Science and Technology have always shown low levels in recognizing and using collocations. Being a missing component in grammar or vocabulary content, students seem to be unaware of their importance and consequently, their skills of writing are highly negatively affected due to the lack of that training.

The present study investigates the effectiveness of incidental learning versus explicit instruction of lexical collocation in developing receptive and productive collocational knowledge and the writing quality of EFL English Majors. It also offers some insight into the correlation between the lexical knowledge of collocations and writing quality among English majors. This raises the following questions:

1- What is the effect of incidental learning of lexical collocations in developing receptive collocational knowledge among English majors?

2- What is the effect of incidental learning of lexical collocations in developing productive collocational knowledge among English majors?

3- What is the effect of incidental learning of lexical collocations in developing quality of writing among English majors?

4- What is the effect of explicit instruction of lexical collocations in developing receptive collocational knowledge among English majors?

5- What is the effect of explicit instruction of lexical collocations in developing productive collocational knowledge among English majors?

6- What is the effect of explicit instruction of lexical collocations in developing quality of writing among English majors? 


\section{Dr. Hanan Gamal Mohamed Ebedy}

\section{Hypotheses of the Study}

The following nine hypotheses were formulated:

1- There will be a statistically significant difference at .01 level between the mean scores attained by the experimental group 1(Incidental Learning) and those of the experimental group 2 (Explicit Instruction) in receptive collocational knowledge in favor of Explicit Instruction group.

2- There will be a statistically significant difference at .01 level between the mean scores attained by the experimental group 1(Incidental Learning) and those of the experimental group 2 (Explicit Instruction) in productive collocational knowledge in favor of Explicit Instruction group.

3- There will be a statistically significant difference at .01 level between the mean scores attained by the experimental group 1(Incidental Learning) and those of the experimental group 2 (Explicit Instruction) in the quality of writing in favor of Explicit Instruction group.

4- There will be a statistically significant difference at .01 level between the mean scores attained by the experimental group 1(Incidental Learning) and those of the control group in receptive collocational knowledge in favor of the experimental group 1(Incidental Learning).

5- There will be a statistically significant difference at .01 level between the mean scores attained by the experimental group 1(Incidental Learning) and those of the control group in productive collocational knowledge in favor of the experimental group 1(Incidental Learning).

6- There will be a statistically significant difference at .01 level between the mean scores attained by the experimental group 2 (Explicit Instruction) and those of the control group in receptive collocational knowledge in favor of the experimental group 2 (Explicit Instruction). 


\section{Using Explicit Instruction versus Incidental Learning in Enhancing}

Lexical Collocational Knowledge and Quality of Writing

7- There will be a statistically significant difference at .01 level between the mean scores attained by the experimental group 2 (Explicit Instruction) and those of the control group in productive collocational knowledge in favor of the experimental group 2 (Explicit Instruction).

8- There will be a statistically significant difference at .01 level between the mean scores attained by the experimental group 2 (Explicit Instruction) and those of the control group in the quality of writing in favor of the experimental group 2 (Explicit Instruction).

\section{Purpose of the Study}

The main objective driving this study is to help third year English majors learn how to recognize and produce lexical collocations and transfer that to their writing quality. To realize this, the study sought to adopt a lexical collocation-based training and to probe its effectiveness in developing both receptive and productive collocational knowledge with a view to enhancing writing quality among EFL majors.

\section{Significance of the Study}

The study is particularly significant for the potentially important contributions it would make to the field of English Language Teaching in the following aspects:

1- The present study may be one of the first attempts to draw a comparison between incidental learning and explicit instruction of lexical collocations with a view to developing writing quality among EFL majors.

2- Results of the present study might help familiarize English teacher educators with an insight about an important approach for developing lexical collocations among their target students. 
3- Results of the study would highlight the importance of training EFL majors to develop lexical collocational knowledge both receptively and productively.

4- Results of the study may initiate an attempt to promote teaching lexical collocations in Egypt through raising the awareness of the necessity of presenting this language component explicitly with a view to enhancing native-like writing quality.

5- Results of this study will hopefully be a model of a lexical collocation task which is applicable to EFL setting to improve the students' writing skill.

\section{Delimitations of the Study}

In languages, many lexical collocations exist. The main ones are Verb + Noun, Verb + Adverb, Adjective + Noun, Noun + Adverb, and Adverb + Adjective. Subsequently, as there exists many lexical collocations, this study will confine itself to only two collocations. These collocations are Verb + Noun and Adjective + Noun. Delimiting the scope to these two collocations, the study will be able to investigate the effectiveness of incidental learning versus explicit instruction in enhancing lexical collocational knowledge receptively and productively.

\section{Definition of Terms}

\section{- Lexical Collocations}

The term 'collocation' has its roots in a Latin verb 'collocare' which means 'to set in order / to arrange' (Mahvelati \& Mukundan, 2012, p. 205; and Hsu, 2009). Firth (1957), who brought this term to the field of linguistics after it was first introduced by Palmer (1933), defines it first as "a combination of words associated with each other" for example the word 'night' associates with the word 'dark'. According to Nation (2002, p. 317) as a string of words that "must or should be learned or is best or most conveniently learned as an integral whole or independent 


\section{Using Explicit Instruction versus Incidental Learning in Enhancing}

Lexical Collocational Knowledge and Quality of Writing

entity, rather than by the process of piecing together their component parts."

Definitions of collocation are further proposed by other linguists, making it one of the most frequently defined terms. Lewis (1997, p. 51) refers to collocation as a predictable co-occurrence of lexical items such as make friends, human errors, do homework, fast food etc. Halliday \& Matthiessen (2004, p. 577) term collocation as the co-occurrence tendency of items which are associative. Collocation is further considered as a naturally-sounding combination of words that should be treated as one single building block of language.

Benson et al. (1997) divide collocation into two categories: grammatical and lexical collocation. A lexical collocation is a phrase containing syntagmatic combinations of content words (verbs, nouns, adverbs and adjectives) such as draw a conclusion, heavy traffic, affect deeply, and doctors diagnose. grammatical collocation, on the other hand, is a word combination between a content word (a verb, noun or adjective) and a function / grammatical word (a preposition or particle), and between a content word (a noun or an adjective) and a grammatical structure (to infinitive or that clause). The examples include argument about, by accident, account for, depend on, and interested in. In this study, collocation operationally refers to the relations between words that co-occur habitually at the lexical level.

\section{- Incidental Learning}

Incidental learning is defined as learning something without awareness by engaging in meaning-focused communicative activities such as reading or listening (Hulstijn, 2003). Other researchers claim that "students learn the target items as a byproduct of reading a text for comprehension of the content rather than for learning that items in that text" (Zaferanieh and 


\section{Dr. Hanan Gamal Mohamed Ebedy}

Behrooznia, 2011, p. 122). In the present study, it is learning of lexical collocations through sufficient exposure to the target items in reading.

\section{- Explicit instruction}

According to Ellis (1994), the most characteristic feature distinguishing explicit learning is the presence of "conscious operations" (p. 1), a notion also referred to as the presence of "awareness at the point of learning" (Schmidt, 1994a, p. 20). More recently, Ellis (2012) elaborates that in incidental learning, learners remain unaware of the learning that has taken place, although it is evident in the behavioral responses they make. Thus, learners cannot verbalize what they have learned. In the case of explicit instruction, learners are aware that they have learned something and can verbalize what they have learned. In the present study, explicit instruction of lexical collocations refers to fully guided practice in which the instructors explain, demonstrate and model how word combinations occur together to signify the meaning intended.

\section{- Quality Writing}

According to Peha (2003), it consists of: Ideas that are interesting and important, organization that is logical and effective, voice that is individual and appropriate, word choice that is memorable and specific, sentence fluency that is expressive and smooth, conventions that are correct and communicative. Donovan (2017) defines quality writing as clear and focused content, relevant ideas, unique and identifiable voice, precise word choice, grammatical and appropriate style, and thought-provoking ideas. In the present study, quality writing refers to participants' production of a piece of writing that is native-like in clarity, accuracy, fluency and appropriacy of giving the meaning using individual words and word combinations. 


\section{Using Explicit Instruction versus Incidental Learning in Enhancing}

Lexical Collocational Knowledge and Quality of Writing

\section{Method of the Study}

The study adopts a quasi-experimental design, comparing the performance of the experimental groups (Incidental Learning), and the (Explicit Instruction) to the control group to probe the effectiveness of a proposed lexical collocation-based training in developing receptive and productive lexical collocational knowledge to transfer that to EFL majors' writing quality.

\section{Participants of the Study}

The population of the study is the third year EFL majors at the Faculty of Language and Translation, Misr University for Science and Technology. Participants consisted of 60 students who were randomly assigned to two experimental groups; experimental group 1(Incidental Learning), the experimental group 2 (Explicit Instruction) and one control group. Twenty EFL students represented the experimental group1 (Incidental Learning), twenty EFL students represented the experimental group 2 (Explicit Instruction) and twenty students represented the control group.

\section{Instruments of the Study}

Two instruments are required in the present study; a lexical collocation Test which consists of two parts, namely, receptive and productive, and a writing quality test.

\section{The first instrument}

In part one of the test, the receptive lexical collocation, students are required to identify the appropriate collocation use out of two distractors given whether they were verb +noun, or adjective +noun delimited by the scope of the study. In part two of the test, the productive lexical collocations, students are required both to supply a missing verb or an adjective that collocates appropriately with the noun provided, and to read an essay and replace miscollocations with correct collocations. Miscollocations (verb 


\section{Dr. Hanan Gamal Mohamed Ebedy}

+noun, and adjective +noun) are embedded in the essay given. The collocations are highlighted and the wrong collocates are marked in boldface. Participants are reminded that the words in boldface need to be replaced with either correct verbs or adjectives.

\section{The second instrument}

Students are required to write an essay describing an embarrassing moment in their lives or a happy unforgettable experience they would remember with pleasure, in which they are asked to use as many lexical collocations as they could providing that they are fitting for the context of the topic.

\section{Scoring of the writing test}

A scoring rubric consisting of a number of descriptors was developed by the researcher for scoring the students' written product. The students' performance will range from excellent, very good, good, fair and unsatisfactory.

\section{Collocation Material Sources}

The present study adopted both Cambridge Collocations in Use and Online Oxford Collocation Dictionary (https://www.freecollocation.com/) for the following reasons:

1. The collocations selected in Cambridge Collocations in Use were fundamentally picked from those classified as important by the Cambridge English Corpus which is extracted from a wide range of current living sources such as advertising, emails, newspapers, radio and television. It comprises hundreds of collocations in natural native contexts that suit intermediate students and the higher levels of English majoring students. The book provides students with hundreds of exercises of collocations in an ideal native context. The book contains an answer key that may help learners reinforce their learning of collocations and be assured about the accuracy of their answers. 


\section{Using Explicit Instruction versus Incidental Learning in Enhancing}

Lexical Collocational Knowledge and Quality of Writing

\section{Online Oxford Collocation Dictionary shows readers how} words combine with each headword: verbs, adjectives, nouns adverbs, common phrases and prepositions. The dictionary has the advantage of familiarizing readers with the natural use of collocations in context, giving prominence to register and grammatical use. Parts of speech and meaning are also highlighted.

\section{Procedures of the Study}

The current study was conducted in ten weeks. Both the lexical collocations test and the writing quality test were administered for the three groups (experimental 1, experimental 2, and the control) to measure the extent the participants benefitted from the training they received from the two sources identified in the materials section above. The (experimental group1) was taught implicitly lexical collocations through teaching reading comprehension passages and requiring them to answer questions containing lexical collocations incidentally. In other words, the learners were provided with exemplars of the lexical collocations in different texts. They were taught the selected texts without explaining the lexical collocations explicitly to them. Moreover, the experimental group 2 (explicit instruction) received training sessions on lexical collocations using the two sources referred to above. More precisely, the teacher tried to draw learners' attentions to lexical collocations such as explaining different kinds of collocations, while the control group did not receive any implicit or explicit collocation instruction. Finishing the treatment, the lexical collocations test and the writing quality test were administered for the three groups after training. The data was collected and tabulated through SPSS and analyzed using t-test to compare the mean scores of students' performance on the test. 


\section{Dr. Hanan Gamal Mohamed Ebedy}

\section{Results and Discussion}

In order to test the research hypotheses, the Statistical Package (SPSS/PC+) was used to calculate the t-value for testing the difference between the mean scores of the two experimental groups and the control group on the test of lexical collocations and the writing quality test. In the following section, a discussion of the hypotheses is provided in order to investigate the final results of the treatment.

\section{The first hypothesis}

The results for the first research hypothesis of the study (There will be a statistically significant difference at .01 level between the mean scores attained by the experimental group 1(Incidental Learning) and those of the experimental group 2 (Explicit Instruction) in receptive collocational knowledge in favor of Explicit Instruction group) are presented in Table (1).

Table (1): t-test results comparing the two experimental groups in receptive collocational knowledge

\begin{tabular}{|c|c|c|c|c|c|c|c|}
\hline & Group & $\mathbf{N}$ & Mean & $\begin{array}{c}\text { Std. } \\
\text { Deviation }\end{array}$ & df & $\mathbf{t}$ & Sig. (2 tailed) \\
\hline \multirow{2}{*}{ Receptive } & $\begin{array}{c}\text { Incidental } \\
\text { Learning }\end{array}$ & 20 & 24.81 & 7.62 & \multirow{2}{*}{18} & 4.95 & 0.000 \\
\cline { 2 - 5 } & $\begin{array}{c}\text { Explicit } \\
\text { Instruction }\end{array}$ & 20 & 31.72 & 4.87 & & \\
\hline
\end{tabular}

Results in table (1) indicate that the experimental group 1 (Incidental Learning) students' mean score in receptive collocational knowledge was (24.81) whereas, the experimental group 2 (Explicit Instruction) students' mean score was (31.72). These results indicate that the higher mean is in favour of explicit instruction group. To sum up, the t-test of the paired sample results about the difference between the students' mean scores in receptive collocational 
Using Explicit Instruction versus Incidental Learning in Enhancing

Lexical Collocational Knowledge and Quality of Writing

knowledge was statistically significant in favor of the explicit instruction. So, the first hypothesis is accepted.

\section{The second hypothesis}

The results for the second research hypothesis of the study (There will be a statistically significant difference at .01 level between the mean scores attained by the experimental group 1(Incidental Learning) and those of the experimental group 2 (Explicit Instruction) in productive collocational knowledge in favor of Explicit Instruction group) are presented in Table (2).

Table (2): t-test results comparing the two experimental groups in productive collocational knowledge

\begin{tabular}{|c|c|c|c|c|c|c|c|}
\hline & Group & $\mathbf{N}$ & Mean & $\begin{array}{c}\text { Std. } \\
\text { Deviation }\end{array}$ & $\mathbf{d f}$ & $\mathbf{t}$ & Sig. (2 tailed) \\
\hline \multirow{2}{*}{ productive } & $\begin{array}{c}\text { Incidental } \\
\text { Learning }\end{array}$ & 20 & 23.69 & 7.41 & \multirow{2}{*}{18} & 7.78 & 0.000 \\
\cline { 2 - 5 } & $\begin{array}{c}\text { Explicit } \\
\text { Instruction }\end{array}$ & 20 & 30.36 & 6.98 & & & \\
\hline
\end{tabular}

Results in table (2) show that the experimental group 1 (Incidental Learning) students' mean score in productive collocational knowledge is (23.69) whereas, the experimental group 2 (Explicit Instruction) students' mean score was (30.36). These results indicate that the higher mean is in favour of explicit instruction group. To sum up, the t-test of the paired sample results about the difference between the students' mean scores in productive collocational knowledge is statistically significant in favor of the explicit instruction. So, the second hypothesis is accepted. 


\section{Dr. Hanan Gamal Mohamed Ebedy}

\section{The third hypothesis}

The results for the third research hypothesis of the study (There will be a statistically significant difference at .01 level between the mean scores attained by the experimental group 1(Incidental Learning) and those of the experimental group 2 (Explicit Instruction) in the quality of writing in favor of Explicit Instruction group) are presented in Table (3).

Table (3): t-test results comparing the two experimental groups in the quality of writing

\begin{tabular}{|c|c|c|c|c|c|c|c|}
\hline & Group & $\mathbf{N}$ & Mean & $\begin{array}{c}\text { Std. } \\
\text { Deviation }\end{array}$ & df & $\mathbf{t}$ & Sig. (2 tailed) \\
\hline \multirow{2}{*}{ Writing } & $\begin{array}{c}\text { Incidental } \\
\text { Learning }\end{array}$ & 20 & 18.80 & 2.81 & \multirow{2}{*}{18} & 4.04 & 0.000 \\
\cline { 2 - 5 } & $\begin{array}{c}\text { Explicit } \\
\text { Instruction }\end{array}$ & 20 & 22.17 & 3.83 & & \\
\hline
\end{tabular}

Results in table (3) reveal that the experimental group 1 (Incidental Learning) students' mean score in the quality of writing is (18.80) whereas, the experimental group 2 (Explicit Instruction) students' mean score is (22.17). These results indicate that the higher mean is in favour of explicit instruction group. To sum up, the t-test of the paired sample results about the difference between the students' mean scores in the quality of writing is statistically significant in favor of the explicit instruction. So, the third hypothesis is accepted.

\section{The fourth hypothesis}

The results for the fourth research hypothesis of the study (There will be a statistically significant difference at .01 level between the mean scores attained by the experimental group 1(Incidental Learning) and those of the control group in receptive collocational knowledge in favor of the experimental group 1(Incidental Learning) are presented in Table (4). 


\section{Using Explicit Instruction versus Incidental Learning in Enhancing}

Lexical Collocational Knowledge and Quality of Writing

Table (4): t-test results comparing the experimental group

1(Incidental Learning) and the control group in receptive collocational knowledge

\begin{tabular}{|c|c|c|c|c|c|c|c|}
\hline & Group & $\mathbf{N}$ & Mean & $\begin{array}{c}\text { Std. } \\
\text { Deviation }\end{array}$ & df & $\mathbf{t}$ & Sig. (2 tailed) \\
\hline \multirow{2}{*}{ Receptive } & $\begin{array}{c}\text { Incidental } \\
\text { Learning }\end{array}$ & 20 & 24.81 & 7.62 & 18 & 5.78 & 0.000 \\
\cline { 2 - 7 } & $\begin{array}{c}\text { Control } \\
\text { Group }\end{array}$ & 20 & 20.34 & 5.52 & & \\
\hline
\end{tabular}

Results in table (4) display that the experimental group 1 (Incidental Learning) students' mean score in receptive collocational knowledge is (24.81) whereas, the control group students' mean score is (20.34). These results indicate that the higher mean is in favour of incidental learning group. To sum up, the t-test of the paired sample results about the difference between the students' mean scores in receptive collocational knowledge is statistically significant in favor of the incidental learning. So, the fourth hypothesis is accepted.

\section{The fifth hypothesis}

The results for the fifth research hypothesis of the study (There will be a statistically significant difference at .01 level between the mean scores attained by the experimental group 1(Incidental Learning) and those of the control group in productive collocational knowledge in favor of the experimental group 1(Incidental Learning) are presented in Table (5).

Table (5): t-test results comparing the experimental group 1(Incidental Learning) and the control group in productive collocational knowledge

\begin{tabular}{|c|c|c|c|c|c|c|c|}
\hline & Group & $\mathbf{N}$ & Mean & $\begin{array}{c}\text { Std. } \\
\text { Deviation }\end{array}$ & $\mathbf{d f}$ & $\mathbf{t}$ & Sig. (2 tailed) \\
\hline \multirow{2}{*}{ productive } & $\begin{array}{c}\text { Incidental } \\
\text { Learning }\end{array}$ & 20 & 23.69 & 7.41 & \multirow{2}{*}{18} & 3.31 & 0.000 \\
\cline { 2 - 7 } & Control Group & 20 & 21.48 & 6.48 & & \\
\hline
\end{tabular}

العدد الخامس والاربعون (الجزء الاول) ا I.r.

(34)

مجلة كلية التربية- جامعة عين شمس 


\section{Dr. Hanan Gamal Mohamed Ebedy}

Results in table (5) illustrate that the experimental group 1 (Incidental Learning) students' mean score in productive collocational knowledge is (23.69) whereas, the control group students' mean score is (21.48). These results indicate that the higher mean is in favour of incidental learning group. To sum up, the t-test of the paired sample results about the difference between the students' mean scores in productive collocational knowledge is statistically significant in favor of the incidental learning. So, the fifth hypothesis is accepted.

\section{The sixth hypothesis}

The results for the sixth research hypothesis of the study (There will be a statistically significant difference at .01 level between the mean scores attained by the experimental group 2 (Explicit Instruction) and those of the control group in receptive collocational knowledge in favor of the experimental group 2 (Explicit Instruction) are presented in Table (6).

Table (6): t-test results comparing the experimental group 2

(Explicit Instruction) and the control group in receptive collocational knowledge

\begin{tabular}{|c|c|c|c|c|c|c|c|}
\hline & Group & $\mathbf{N}$ & Mean & $\begin{array}{c}\text { Std. } \\
\text { Deviation }\end{array}$ & df & $\mathbf{t}$ & Sig. (2 tailed) \\
\hline \multirow{2}{*}{ Receptive } & $\begin{array}{c}\text { Explicit } \\
\text { Instruction }\end{array}$ & 20 & 31.72 & 4.87 & \multirow{2}{*}{18} & 12.49 & 0.000 \\
\cline { 2 - 5 } & $\begin{array}{c}\text { Control } \\
\text { Group }\end{array}$ & 20 & 20.34 & 5.52 & & \\
\hline
\end{tabular}

Results in table (6) reveal that the experimental group 2 (Explicit Instruction) students' mean score in receptive collocational knowledge is (31.72) whereas, the control group students' mean score is (20.34). These results indicate that the higher mean is in favour of explicit instruction group. To sum up, the t-test of the paired sample results about the difference between the students' mean scores in receptive collocational knowledge is statistically 
Using Explicit Instruction versus Incidental Learning in Enhancing

Lexical Collocational Knowledge and Quality of Writing

significant in favor of the explicit instruction. So, the sixth hypothesis is accepted.

\section{The seventh hypothesis}

The results for the seventh research hypothesis of the study (There will be a statistically significant difference at .01 level between the mean scores attained by the experimental group 2 (Explicit Instruction) and those of the control group in productive collocational knowledge in favor of the experimental group 2 (Explicit Instruction) are presented in Table (7).

Table (7): t-test results comparing the experimental group 2

(Explicit Instruction) and the control group in productive collocational knowledge

\begin{tabular}{|c|c|c|c|c|c|c|c|}
\hline & Group & $\mathbf{N}$ & Mean & $\begin{array}{c}\text { Std. } \\
\text { Deviation }\end{array}$ & df & t & Sig. (2 tailed) \\
\hline \multirow{2}{*}{ productive } & $\begin{array}{c}\text { Explicit } \\
\text { Instruction }\end{array}$ & 20 & 30.36 & 6.98 & \multirow{2}{*}{18} & 9.98 & 0.000 \\
\cline { 2 - 6 } & $\begin{array}{c}\text { Control } \\
\text { Group }\end{array}$ & 20 & 21.48 & 6.48 & & \\
\hline
\end{tabular}

Results in table (7) demonstrate that the experimental group 2 (Explicit Instruction) students' mean score in productive collocational knowledge is (30.36) whereas, the control group students' mean score is (21.48). These results indicate that the higher mean is in favour of explicit instruction group of the test. To sum up, the t-test of the paired sample results about the difference between the students' mean scores in productive collocational knowledge is statistically significant in favor of the explicit instruction. So, the seventh hypothesis is accepted.

\section{The eighth hypothesis}

The results for the eighth research hypothesis of the study (There will be a statistically significant difference at .01 level between the mean scores attained by the experimental group 2 


\section{Dr. Hanan Gamal Mohamed Ebedy}

(Explicit Instruction) and those of the control group in the quality of writing in favor of the experimental group 2 (Explicit Instruction) are presented in Table (8).

Table (8): t-test results comparing the experimental group 2 (Explicit Instruction) and the control group in the quality of writing

\begin{tabular}{|c|c|c|c|c|c|c|c|}
\hline & Group & N & Mean & $\begin{array}{c}\text { Std. } \\
\text { Deviation }\end{array}$ & df & t & Sig. (2 tailed) \\
\hline \multirow{2}{*}{ Writing } & $\begin{array}{c}\text { Explicit } \\
\text { Instruction }\end{array}$ & 20 & 22.17 & 3.83 & \multirow{2}{*}{18} & 3.52 & 0.000 \\
\cline { 2 - 7 } & $\begin{array}{c}\text { Control } \\
\text { Group }\end{array}$ & 20 & 16.38 & 2.32 & & \\
\hline
\end{tabular}

Results in table (8) manifest that the experimental group 2 (Explicit Instruction) students' mean score in the quality of writing was (22.17) whereas, the control group students' mean score is (16.38). These results indicate that the higher mean is in favour of explicit instruction group. To sum up, the t-test of the paired sample results about the difference between the students' mean scores in the quality of writing is statistically significant in favor of the explicit instruction. So, the eighth hypothesis is accepted. The data manifested that outperforming of both experimental groups in comparison to the control group. A difference of significance is observed between the explicit instruction and implicit learning groups. The statistical analysis of the data revealed the superiority of explicit instruction method over the implicit learning in enhancing lexical collocational knowledge.

The results revealed a clear advantage for explicit instruction as the explicit instruction group significantly outperformed the incidental learning group and the control group. The incidental learning group also reflected some collocation gains in the test with better performance than the control group. These results are closely related to the distinction between receptive and productive collocational knowledge. The first type of knowledge seems easier to acquire than the latter which requires the use of more cognitive resources and deeper levels of processing. This finding is consistent 


\section{Using Explicit Instruction versus Incidental Learning in Enhancing}

Lexical Collocational Knowledge and Quality of Writing

with the results reached by (Brashi, 2009; and Zohra, 2015) maintaining that FL learners' productive knowledge of collocations lags behind their receptive knowledge.

The finding also revealed that there was a positive correlation between lexical collocational knowledge and the writing quality among English majors. Explicit instruction appeared to be effective in developing students' writing quality. It is fair to claim, that enriching lexical collocation background seems to enhance writing quality, and language performance overall. Results also show that the mere short experience with lexical collocation has its impact on writing quality and enhances awareness and understanding of the value of the collocation component.

It is worth noting that explicit instruction in the current study involved the presenting concepts by the instructor and the students' writing sentences individually to later receive feedback by the instructor within a whole class activity. Building up meaningful grammatical sentences can boost lexical development due to getting learners involved. According to Hulstijn and Laufer (2001), learning gains increase through tasks requiring more cognitive resources and higher processing. The results of the current study seem highly in congruence with Laufer \& Girasi (2008), Szudarzki (2012), and Szudarski \& Carter (2016), maintaining that incidental learning only proved slightly beneficial, while clear gains were evident for explicit instruction.

Overall, the findings of the present study lend support to the claim made by some scholars in the field (e.g., Richards and Renandya, 2002; and Wray, 2002) that familiarity with collocation help FL learners gain command of written and oral performance. As Segalowitz and Freed (2004) point out , different learning environments offer varied learning opportunities and the learning opportunities in EFL contexts do not seem to support incidental vocabulary learning due to their insufficient FL input and exposure 


\section{Dr. Hanan Gamal Mohamed Ebedy}

(e.g. Peters, Hulstijn, Sercu, \& Lutjeharms, 2009; and Szudarski \& Carter, 2016). Segalowitz and Freed (2004) also highlight that FL learners differ in their aptitude to interact with the learning content encountered.

The findings are consistent with those of other researches, including Bonk, 2000; Nesselhauf, 2003; Macaro \& Masterman, 2006; Huang, 2007; Hsu \& Chiu, 2008; Spada \& Tornita, 2010; Zaferanieh \& Behroozi, 2011; Attar and Allami, 2013; and Shooshtari \& Karimi, 2013. All of these researchers claim that explicit instruction is more effective in teaching collocations than incidental learning methods as it can accelerate the rate of progress of learning and leads to longer retention. With regard to the writing quality, the results of the current study demonstrated that explicit instruction of collocation has a positive effect on students' writing performance. This finding confirms the results of studies conducted by other researchers, such as Liu, 2000; Farghal \& Al-Hamly, 2007; Hsu, 2007; Ebrahimi-Bazzaz \& Arshad-Abd, 2011; and Karami, 2013. However, the findings of the present study go against those of Zarei \& Tondaki (2015), who claim that there is no difference between explicit instruction and incidental learning with regard to their effect on the acquisition of collocation. The difference in the findings of the two studies may be due to different proficiency levels of participants.

The results also indicated that collocation is significant as an EFL teaching method. Within the learning of collocation students become familiar with correct word joining and acceptable meaning. Such a learning environment can be more available with collocation using; moreover, this rich environment helps acquiring language meaning and function. Learners' attempt to find resources for natural use of the language like collocations dictionaries may help them make sense of language item and spare students' time and effort when they want to produce language items correctly. Collocation can be taught via various materials which match different types of learning styles, visual, auditory and kinesthetic.

العدد الخامس والاربعون (الجزء الاول) I r.r

(39)
مجلة كلية التربية- جامعة عين شمس 


\section{Using Explicit Instruction versus Incidental Learning in Enhancing}

Lexical Collocational Knowledge and Quality of Writing

The secret behind a significant performance on collocation may lie in the variety of activities to be presented to students. Practice of collocation activities has the advantage of arousing students' motivation and can be a source of satisfaction for them (Szudarski \& Carter, 2016)

\section{Conclusion}

Awareness of lexical collocation significantly affects both recognition and production of language and enable learners attain more successful communication than idioms, as they are more dynamic in everyday language. Overall, the conclusion drawn from the results of the present study is that explicit instruction of collocation has a great impact on learners' performance. The results showed a clear advantage for explicit learning, however, incidental learning only proved slightly beneficial and still to a lesser extent than explicit instruction. This is in stark contrast with the poor performance of the control group who lagged behind and did not achieve the attempted goal. This is largely due to the absence of explicit instruction of collocation and inadequate exposure to collocation input in the case of the control group. Thus, teachers should put emphasis on the explicit instruction of collocation. In order to write natural and authentic English, FL learners need to be taught collocations explicitly as lack of awareness of features of collocation often causes problems for EFL learners. Consequently, teachers should assume their role of raising students' awareness of collocations, assess their input and evaluate their progress regularly.

The mistaken use of collocations is negatively reflected on students' writing in the form of improper word combination. To write more proficiently, they need to have adequate training on using collocations. Teachers should help the learners develop their collocational knowledge so that they become fluent in English generally and writing specifically. This could be achieved through an explicit instruction of collocations that is based mainly on

$$
\begin{aligned}
& \text { العدد الخامس والاربعون (الجزء الاول) الY. r. } \\
& \text { جملة كلية التربية- جامعة عين شنس }
\end{aligned}
$$




\section{Dr. Hanan Gamal Mohamed Ebedy}

building students' awareness of the most common collocates of a word. Thus, teaching language chunks in the form of lexical collocations is more beneficial to FL learners than teaching individual words. Being so, it would be fruitful to admit the positive effect of training on using collocations both in class and at home. The more students understand how a lexical collocation collocates, the more autonomous and empowered they will be in writing.

It is important for language teachers to enhance the learners' consciousness about the importance of collocations in EFL. Explicit training on using collocations leads to certainty of lexical knowledge and helps learners practice word combinations in natural context rather than individual words Hill (2000) and Woolard (2000). Nesselhauf (2005) also advocates the conscious-raising activities by suggesting that students should be made aware of the phenomenon in which word combinations differ along a scale, ranging from free combinations, collocations to idioms. Teachers are in a position to assess their students' needs of specific types or features of collocations that require added attention. To enhance learners' knowledge of collocations, teachers could train them to link current knowledge to new knowledge (Hill, 2000). Students can be trained to use their existing lexicon to produce more collocations as learners who are "collocationally competent ... will also be far more communicatively competent" (Hill, 2000: 62). 
Using Explicit Instruction versus Incidental Learning in Enhancing

Lexical Collocational Knowledge and Quality of Writing

\section{Recommendations}

Based on the conclusions drawn from the results reached, the following recommendations seem pertinent:

1- The English language curriculum should be enriched with the collocation component with a view to improving language performance.

2- The attempt should be made to draw student-teachers' attention to the benefits of collocation.

3- More exposure to collocations should take place in order to boost teachers' lexical competence through holding workshops and training courses about using collocations.

4- School libraries should be provided with collocation dictionaries and references to be used as language learning sources.

5- More time should be assigned to doing exercises and collocation types -based activities both in class and outside class.

6- Teachers are advised to encourage learners to use collocation in real life situations whether orally or in writing dairies, journals and emails so that English becomes functional in everyday use.

7- EFL students should be required to write assignments involving use of varied types of collocations providing that they fit for the context. 


\section{Dr. Hanan Gamal Mohamed Ebedy}

\section{References}

Alsakran, R. (2011). The productive and receptive knowledge of collocations by advanced Arabic-speaking ESL/EFL learners. (Unpublished $\mathrm{PhD}$ Dissertation. Colorado State University. Colorado).

Amer, M. (2010). Idiomobile for learners of English: A study of learners' usage of a mobile learning application for learning idioms and collocations. (Unpublished PhD Dissertation. Indiana University of Pennsylvania. Indiana).

Attar, E., \& Allami, H. (2013). The effects of teaching lexical collocations on speaking ability of Iranian EFL learners. Theory and Practice in Language Studies, 3(6), 1070-1079.

Bahns, J., \& Eldaw, M. (1993). Should we teach EFL students' collocations? System, 21(1), 101-114.

Barani, F. (2020). The Effect of Story Reading on Incidental Lexical and Grammatical Collocation Learning by Iranian EFL Learners. Beyond Words, 8(1), 10-23.

Benson, M., Benson, E. \& Ilson, R. (1997). The BBI dictionary of English word combinations. John Benjamins Publishing Company.

Biskup, D. (1992). L1 influence on learners' renderings of English collocations: A Polish/German empirical study. In Vocabulary and applied linguistics (pp. 85-93). Palgrave Macmillan, London.

Bonk, W. (2000). Testing ESL learners' knowledge of collocations. ERIC DOC NO. ED 442309.

Brashi, A. (2009). Collocability as a problem in L2 production. Reflection on English Language Teaching, 8(1), 21-34.

Donovan, M. (2017). Eight characteristics of good writing. Retrieved from better writing website.

Ebrahimi-Bazzaz, F., \& Arshad-Abd, S. (2011). The use of verb-noun collocations in writing stories among Iranian EFL learners. English Language Teaching, 4(3), 158-163.

El-Dakhs, D. (2015). The lexical collocational competence of Arab undergraduate EFL learners. International journal of English linguistics, 5(5), 60-74.

El-Dakhs, D., Amroun, F., \& Charlot-Muhammad, M. (2018). What Works Better for Collocation Learning-Explicit Instruction or Incidental Learning? A Case Study of Arab Female 


\section{Using Explicit Instruction versus Incidental Learning in Enhancing}

Lexical Collocational Knowledge and Quality of Writing

Undergraduate Learners of English. Electronic Journal of Foreign Language Teaching, 15(1), 39-54.

Ellis, N. (1994). Consciousness in second language learning: Psychological perspectives on the role of conscious processes in vocabulary acquisition. AILA

Ellis, R. (2012). Implicit and explicit knowledge in second language learning, testing and teaching. Multilingual Matters.

Fahim, M., \& Vaezi, R. (2011). Investigating the Effect of Visually enhanced Input on the Acquisition of Lexical Collocations by Iranian Intermediate EFL Learners: A Case of Verb-noun Lexical Collocations. Journal of Language Teaching \& Research,2(3), 552-560.

Falahi, M., \& Moinzadeh, A. (2012). Effects of Receptive and Productive Tasks on Iranian EFL Students' Learning of Verb-noun Collocations. Journal of Language Teaching \& Research, 3(5), 953-960.

Fan, M. (2009). An exploratory study of collocational use by ESL students-A taskbased approach. System, 37(1), 110-123.

Fan, Y. (2005). Differential effects of attention in second language acquisition of verb-noun collocations. (Unpublished Ph. D. Dissertation. Michigan State University).

Farghal, M., \& Al-Hamly, M. (2007). Lexical collocations in EFL writing. The Journal of Asia TEFL, 4(2), 69-94.

Farghal, M., \& Obiedat, H. (1995). Collocations: A neglected variable in EFL. IRAL: International Review of Applied Linguistics in Language Teaching, 33(4), 315-331.

Fernández, B., \& Schmitt, N. (2015). How much collocation knowledge do L2 learners have?: The effects of frequency and amount of exposure. ITL-international journal of applied linguistics, 166(1), 94-126.

Firth, J. (1957). Modes of meaning. In F. Palmer (ed.), Papers in linguistics (pp. 190-215). Oxford University Press.

Goulart, L. (2019). The use of collocations across proficiency levels: a literature review. BELT-Brazilian English Language Teaching Journal, 10(2), e34129-e34129. 


\section{Dr. Hanan Gamal Mohamed Ebedy}

Granger, S., \& Bestgen, Y. (2014). The use of collocations by intermediate vs. advanced non-native writers: A bigram-based study. International Review of Applied Linguistics in Language Teaching, 52(3), 229-252.

Halliday, M., \& Matthiessen, C. (2004). Introduction to Functional Grammar (4th Edition). Taylor \& Francis.

Hill, J. (2000). Revisiting priorities: From grammatical failure to collocational success. In M. Lewis (Ed.). Teaching collocations: Further development in the lexical approach (pp. 47-69). London: Language Teaching.

Hsu, J. (2007). Lexical collocations and their relation to the online writing of Taiwanese college English majors and non-English majors. Electronic Journal of Foreign Language Teaching, 4, 192-209.

Hsu, J. (2010). The effects of collocation instruction on the reading comprehension and vocabulary learning of Taiwanese college English majors. Asian EFL journal, 12(1), 47-87.

Hsu, J., \& Chiu, C. (2008). Lexical collocations and their relation to speaking proficiency of college EFL learners in Taiwan. Asian EFL Journal, 10(1), 181-204.

Huang, L. (2007). Knowledge of English collocations: An analysis of Taiwanese EFL learners. In C. Luke \& B. Rubrecht (Eds.), Texas papers in foreign language education: Selected proceedings from the Texas Foreign Language Education Conference (pp. 113-132). Texas: Texas University, Austin.

Hulstijn, J. (2003). Incidental and Intentional Learning. Blackwell Publishing.

Hulstijn, J., \& Laufer, B. (2001). Some empirical evidence for the involvement load hypothesis in vocabulary acquisition. Language Learning, 51(3), 539-558.

James, C. (1998). Errors in language learning and use: Exploring error analysis. Routledge.

Karami, M. (2013). Exploring effects of explicit Vs. implicit teaching of collocations on the writing performance of Iranian EFL learners. International Journal of Language Learning and Applied Linguistics World (IJLLALW), 4(4), 197-215.

Kuo, C. (2009). An analysis of the use of collocation by intermediate EFL college students in Taiwan. Arecls, 6, 141-155. 


\section{Using Explicit Instruction versus Incidental Learning in Enhancing}

Lexical Collocational Knowledge and Quality of Writing

Laufer, B., \& Girasi, N. (2008). Form-focused instruction in second language vocabulary learning: A case for contrastive analysis and translation. Applied Linguistics, 29(4), 694-716.

Laufer, B., \& Waldman, T. (2011). Verb-noun collocations in second language writing: A corpus analysis of learners' English. Language learning, 61(2), 647-672.

Lewis, M. (2000). Learning in the lexical approach. In Michael Lewis. (Ed.), Teaching collocation: Further developments in the lexical approach (pp. 155-185). Language Teaching Publications.

Lewis, M., Gough, C., Martínez, R., Powell, M., Marks, J., Woolard, G. C., \& Ribisch, K. H. (1997). Implementing the lexical approach: Putting theory into practice. Language Teaching Publications.

Liu, C. (2000). An empirical study of collocation teaching. The Proceedings of the 17th International Symposium on English Teaching, 165-178

Macaro, E., \& Masterman, L. (2006). Does intensive explicit grammar instruction make all the difference? Language Teaching Research, 10(3), 297-327.

Mahvelati, E. (2019). Explicit and Implicit Collocation Teaching Methods: Empirical Research and Issues. Advances in Language and Literary Studies, 10(3), 105-116.

Mahvelati, E., \& Mukundan, J. (2012). The effects of input flood and consciousness-raising approach on collocation knowledge development of language learners. International Journal of Applied Linguistics and English Literature, 1(6), 182-192.

Nation, I. (2001). Learning vocabulary in another language. Cambridge University Press.

Nation, I., \& Meara, P. (2002) Vocabulary. In N. Schmitt (ed.) An Introduction to Applied Linguistics. (pp. 35-54). Edward Arnold:

Nesselhauf, N. (2003). The use of collocations by advanced learners of English and some implications for teaching. Applied linguistics, 24(2), 223-242.

Nesselhauf, N. (2005). Collocations in a learner corpus. Amsterdam: John Benjamins Publishing Company.

Palmer, H. (1933). Second interim report on English collocations. In the Tenth Annual Conference of English Teachers under the Auspices 


\section{Dr. Hanan Gamal Mohamed Ebedy}

of the Institute for Research in English Teaching. Tokyo Institute for Research in English Teaching.

Peha, S. (2003). Looking for Quality in Student Writing: Learning to See the Things Kids Can Do So We Can Teach Them to Do the Things They Can't. Retrieved from: Teaching that Makes Sense website.

Peters, E., Hulstijn, J., Sercu, L., \& Lutjeharms, M. (2009) Learning L2 German vocabulary through reading: The effect of three enhancement techniques compared. Language Learning, 59(1), 113-51.

Rahim, H., Hua, T., \& Salehuddin, K. (2012). Collocations in Malaysian English learners' writing: A corpus-based error analysis. $3 L$ : language, linguistics, literature, 17. 31-44.

Richards, J., \& Renandya, W. (2002). Methodology in language teaching: An anthology of current practice. Cambridge: Cambridge University Press.

Schmitt, N. (2010). Researching vocabulary: A vocabulary research manual. Springer.

Seesink, M. (2007). Using blended instruction to teach academic vocabulary collocations: A case study. (Unpublished $\mathrm{PhD}$ Dissertation. West Virginia University. Virginia).

Segalowitz, N., \& Freed, B. (2004). Context, contact, and cognition in oral fluency acquisition. Studies in Second Language Acquisition, 26, 173-199.

Shokouhi, H., \& Mirsalari, G. (2010). Collocational Knowledge versus General Linguistic Knowledge among Iranian EFL Learners. TESL-EJ, 13(4).

Shooshtari, Z., \& Karimi, N. (2013). Lexical collocation instruction and its impact on Iranian non-academic EFL learners' speaking ability. Journal of Language Teaching and Research, 4(4), 767-776.

Siyanova, A., \& Schmitt, N. (2008). L2 learner production and processing of collocation: A multi-study perspective. Canadian Modern Language Review, 64(3), 429-458.

Spada, N. \& Tornita, Y. (2010). Interaction between type of instruction and type of language feature: A meta-analysis. Language Learning, 60(2), 263-308. 


\section{Using Explicit Instruction versus Incidental Learning in Enhancing}

Lexical Collocational Knowledge and Quality of Writing

Szudarski, P. (2012). Effects of meaning- and form-focused instruction on the acquisition of verb-noun collocations in L2 English. Journal of Second Language Teaching and Research, 1(2), 3-37.

Szudarski, P., \& Carter, R. (2016). The role of input flood and input enhancement in EFL learners' acquisition of collocations. International Journal of Applied Linguistics, 26(2), 245-265.

Webb, S., \& Kagimoto, E. (2009). The effects of vocabulary learning on collocation and meaning. Tesol Quarterly, 43(1), 55-77.

Webb, S., \& Kagimoto, E. (2010). Learning collocations: Do the number of collocates, position of the node word, and synonymy affect learning? Applied Linguistics, 32(3), 259-276.

Woolard, G. (2000). Collocation- encouraging learner independence. In M. Lewis (Ed.). Teaching collocations: Further development in the lexical approach (pp. 28-46). London: Language Teaching Publications.

Wray, A. (2000). Formulaic sequences in second language teaching: Principle and practice. Applied Linguistics, 21(4), 463-489.

Wray, A. (2002). Formulaic language and the lexicon. Cambridge: Cambridge University Press.

Zaferanieh, E., \& Behrooznia, S. (2011). On the impacts of four collocation instructional methods: Web-based concordancing vs. traditional method, explicit vs. implicit Instruction. Studies in Literature and Language, 3(3), 120-126.

Zarei, A. \& Tondaki, N. (2015). The Effects of explicit and implicit instructional techniques on Iranian EFL learners' comprehension and production of lexical collocations. Academie Royale des Seances Doutr-Mer Bulletin des Seances, 4(2), 122-131.

Zohra, H. (2015). Collocations as erroneous patterns in EFL learning: The case of third-year LMD students at Tlemcen University (Unpublished master's thesis). Tlemcen University, Algeria. 